\title{
Associations of a Polymorphic AP-2 Binding Site in the 5'-Flanking Region of the Bovine $\beta$-Lactoglobulin Gene with Milk Proteins
}

\author{
A. W. Kuss, J. Gogol, and H. Geldermann \\ Department of Animal Breeding and Biotechnology, University of Hohenheim, \\ D-70593 Stuttgart, Germany
}

\begin{abstract}
Studies on a polymorphic position (R10) in an Activator-Protein-2 (AP-2) binding site of the bovine $\beta$-Lactoglobulin $(\beta$-Lg) gene promoter region and quantitative traits of individual milk proteins were based on material from 79 German Holstein Friesian (HF) and 61 Simmental (Sm) cows. At least four milk samples per cow were analyzed with alkaline Urea-PAGE in combination with densitometry for quantification of individual milk proteins. The two alleles of the R10 single nucleotide polymorphism (SNP) carry either $\mathrm{G}$ or $\mathrm{C}$ in position $-435 \mathrm{bp}$ of the $\beta$-Lg promoter region. $\mathrm{G}$ - and $\mathrm{C}$-alleles were found in $\mathrm{Sm}$ with nearly equal frequencies, while in $\mathrm{HF}$ the C-allele frequency was higher (0.73) than that of the Gallele. In both breeds, the R10 G-homozygotes had higher $(P<0.001)$ amounts of $\beta$-Lg secreted per day and proportion of $\beta$-Lg in milk protein compared with the C-homozygotes. A similar association was found for $\alpha$-lactalbumin, whereas the relative proportions and daily secreted amounts of caseins $\left(\alpha_{\mathrm{S} 1}, \beta, \kappa\right)$ showed lower values in $\beta$ Lg R10 G-homozygotes. A positive association $(P<0.001)$ of R10 CC with milk yield has also been observed and indicates a close proximity of the $\beta$-Lg locus to a candidate gene for this trait. The association between the SNP in the AP-2 binding site of the $\beta$ - Lg gene and its gene product can be explained as the result of differences in protein binding activity, and, therefore, allele specific differences in gene expression. Thus, our study clearly links a DNA polymorphism of molecular function very closely with in vivo expression parameters of the same locus.
\end{abstract}

(Key words: Activator Protein-2, $\beta$-Lactoglobulin, polymorphism, milk protein, milk yield)

Abbreviation key: AP-2 = Activator protein 2, $\beta$-Lg $=$ $\beta$-Lactoglobulin, $\mathbf{H F}=$ German Holstein Friesian, RFLP $=$ restriction fragment length polymorphism, $\mathbf{S m}=\mathbf{S i m}$ mental, SNP = single nucleotide polymorphism.

Received July 17, 2002.

Accepted January 5, 2003.

Corresponding author: H. Geldermann; e-mail: tzunihoh@ uni-hohenheim.de.

\section{INTRODUCTION}

$\beta$-Lactoglobulin $(\boldsymbol{\beta}$ - $\mathbf{L g})$ is the major whey protein in the milk of ruminants and several nonruminant species (for review see Perez and Calvo, 1995). Polymorphisms have been found not only in the open reading frame of the $\beta$-Lg encoding gene which result in protein variants (Aschaffenburg and Drewry, 1955; 1957; Braunitzer et al., 1973; Bell et al., 1981; Eigel et al., 1984; GodovacZimmerman et al., 1990; 1996), but also in noncoding areas such as the $5^{\prime}$-flanking region (Wagner et al., 1994).

Associations between $\beta$-Lg protein variants and milk protein yield and composition have been observed by several authors (e.g. McLean et al., 1984; Lunden et al., 1997) but their molecular basis remains unclear. Correlations between single strand conformation polymorphisms in regulatory sequences of the $\beta$-Lg gene and milk performance traits have been reported but the effects could not be assigned to specific point mutations (Kaminski and Zabolewicz, 2000).

Ehrmann et al. (1997a), who found close associations between polymorphisms in the $5^{\prime}$-flanking region and proportion in milk protein as well as amount of $\beta$ - $\mathrm{Lg}$ in bovine milk, suggested that differences in these parameters are due to different allelic influences on gene expression. Their study, however, included cows from several breeds and trait evaluation was in many cases based on one observation per cow only. Furthermore, the polymorphic sites were not analyzed for regulatory significance. Therefore, our study is focused on a single nucleotide polymorphism (SNP) in an Activator Protein 2 (AP-2) binding site within the $5^{\prime}$-flanking region of the $\beta$-Lg gene. Pronounced differences in protein binding capacity of the variants of this locus have been observed (Lum et al., 1997; Kock, 1998), thus allowing for a causal interpretation of associations between the gene variants and quantitative characteristics of the gene product. In addition to that, our experiments are based on large herds and at least four observations per cow, so genetic effects could be analyzed with high accuracy.

\section{MATERIALS AND METHODS}

\section{Animals}

Samples and data were collected between April 1997 and March 1999 from 79 cows of a German Holstein 
Table 1. Structure of herds.

a) $\mathrm{Sm}$

b) $\mathrm{HF}$

\begin{tabular}{|c|c|c|c|c|c|c|c|c|c|c|c|}
\hline & $\begin{array}{l}\text { Offspring } \\
\text { per } \\
\text { Parent }\end{array}$ & Sires & $\begin{array}{l}\Sigma \\
\text { Offspring } \\
\text { (Sires) }\end{array}$ & Dams & $\begin{array}{l}\Sigma \\
\text { Offspring } \\
\text { (Dams) }\end{array}$ & & $\begin{array}{l}\text { Offspring } \\
\text { per } \\
\text { Parent }\end{array}$ & Sires & $\begin{array}{l}\Sigma \\
\text { Offspring } \\
\text { (Sires) }\end{array}$ & Dams & $\begin{array}{l}\Sigma \\
\text { Offspring } \\
\text { (Dams) }\end{array}$ \\
\hline & 1 & 30 & 30 & 51 & 51 & & 1 & 32 & 32 & 59 & 59 \\
\hline & 2 & 5 & 10 & 5 & 10 & & 2 & 6 & 12 & 7 & 14 \\
\hline & 3 & 1 & 3 & - & - & & 3 & 5 & 15 & 2 & 6 \\
\hline & 4 & 1 & 4 & - & - & & 4 & 2 & 8 & - & - \\
\hline & 14 & $1^{1}$ & 14 & - & - & & 5 & 1 & 5 & - & - \\
\hline \multirow{2}{*}{ Total } & & 38 & 61 & 56 & 61 & & 7 & 1 & 7 & - & - \\
\hline & & & & & & Total & & 47 & 79 & 68 & 79 \\
\hline
\end{tabular}

${ }^{1}$ Sire (Genotype GG) with 14 daughters which were excluded in a second stage of analysis of variance in order to examine possible pedigree effects.

Friesian (HF) herd and 61 cows of a Simmental (Sm) herd, both from experimental stations of the University of Hohenheim. Pedigrees of the animals are summarized in Table 1.

\section{Milk Samples}

At least four milk samples per cow were collected in intervals of eight weeks during lactation. Fat was removed after centrifugation (10 min at $4550 \times \mathrm{g}$ and $4^{\circ} \mathrm{C}$ ), and the nonfat samples were stored at $-80^{\circ} \mathrm{C}$.

\section{Quantification of Milk Proteins}

Milk proteins were separated by vertical Urea-PAGE (8 M Urea, 8.4\% Acrylamide; see Ehrmann et al., 1997b). The gels were then stained (staining buffer: $8 \% \mathrm{w} / \mathrm{v}$ TCA, $26.7 \%$ v/v Methanol, 9.3\% v/v Acetic Acid, 0.033\% w/v CBB R250) overnight with agitation. After standardized destaining (29\% v/v Methanol, 5\% v/v Acetic Acid; $4 \mathrm{~h}$ with agitation), milk protein fractions ( $\alpha$-s1-Casein, $\beta$ Casein, $\kappa$-Casein, $\alpha$-Lactalbumin, $\beta$-Lactoglobulin) were quantified using a densitometer (ATH Elscript 400, Hirschmann, Germany) together with software of the manufacturer.

\section{Typing of Polymorphic Milk Proteins}

Isoelectric focusing (see Ehrmann et al., 1997b) was used for identification of $\beta$ - $\mathrm{Lg}$ protein variants $\mathrm{A}$ and $\mathrm{B}$. Polyacrylamide gels (4.65\% Acrylamide) were prefocused for $350 \mathrm{Vh}(25 \mathrm{~min})$ and after sample application focused for $3500 \mathrm{Vh}$ (95 min). Instrument settings were: $2000 \mathrm{~V}, 20 \mathrm{~mA}, 30 \mathrm{~W}$. This was followed by $500 \mathrm{Vh}$ with $20 \mathrm{~mA}$ and $30 \mathrm{~W}$. The anode buffer was $1 \mathrm{M} \mathrm{NaOH}$ and the cathode buffer was $1 \mathrm{M} \mathrm{H}_{3} \mathrm{PO}_{4}$.

\section{Blood Samples and DNA-Isolation}

In order to be able to trace sampling errors, two blood samples per animal were taken. Genomic DNA was pre- pared using the NucleoSpin Blood Quick Pure kit (Macherey Nagel, Düren, Germany) according to the instructions of the manufacturer.

\section{Genotyping of DNA Variants}

A fragment of the bovine $\beta$-Lg $5^{\prime}$-flanking region between $-795 \mathrm{bp}$ and $+58 \mathrm{bp}$ was amplified from genomic DNA by PCR.

Forward primer: GGGGGTATCAGCAACACACCCAGC ACCAG

Reverse primer: GGGAAGCTTCAAGCAGGAGGCACT TCATG.

The amplicon was digested with Fnu4HI (New England Biolabs, Frankfurt, Germany) and subsequently submitted to agarose gel analysis for the restriction fragment length polymorphism (RFLP) determination of the R10 site (SNP at $-435 \mathrm{bp}$, defined by Wagner et al., 1994). Genotype nomenclature refers to the respective nucleotide in position -435 . Fragment lengths were 294/256/ 145 bp for C-homozygotes, 294/172/145 bp for G-homozygotes and 294/256/172/145 bp for heterozygotes.

\section{Statistical Analysis of Associations Between Genotypes and Trait Values}

The GLM-Procedure of SAS, version 6.12, was applied within breed, using the following model:

$$
\begin{aligned}
\mathrm{Y}_{\mathrm{ijklmn}}= & \mu+\mathrm{MFL}_{\mathrm{i}}+\mathrm{A}_{\mathrm{ij}}+\mathrm{L}_{\mathrm{k}}+\mathrm{LS}_{1}+\mathrm{S}_{\mathrm{m}}+ \\
& \mathrm{b}_{\mathrm{l}}\left(\mathrm{C}_{\mathrm{ijklmn}}-\overline{\mathrm{C}}\right)+\mathrm{b}_{2}\left(\mathrm{C}^{2}{ }_{\mathrm{ijklmn}}-\overline{\mathrm{C}}^{2}\right)+\mathrm{e}_{\mathrm{ijkl} \mathrm{mn}}
\end{aligned}
$$

where

$$
\begin{aligned}
\mathrm{Y}_{\mathrm{ijklmn}} & =\text { trait value } \\
\mu & =\text { population mean } \\
\mathrm{MFL}_{\mathrm{i}} & =\text { fixed effect of marker genotype } \\
\mathrm{A}_{\mathrm{ij}} & =\text { fixed effect of animal } \mathrm{j} \text { within geno- } \\
& \text { type } \mathrm{i} \\
\mathrm{L}_{\mathrm{k}} & =\text { fixed effect of lactation number }
\end{aligned}
$$



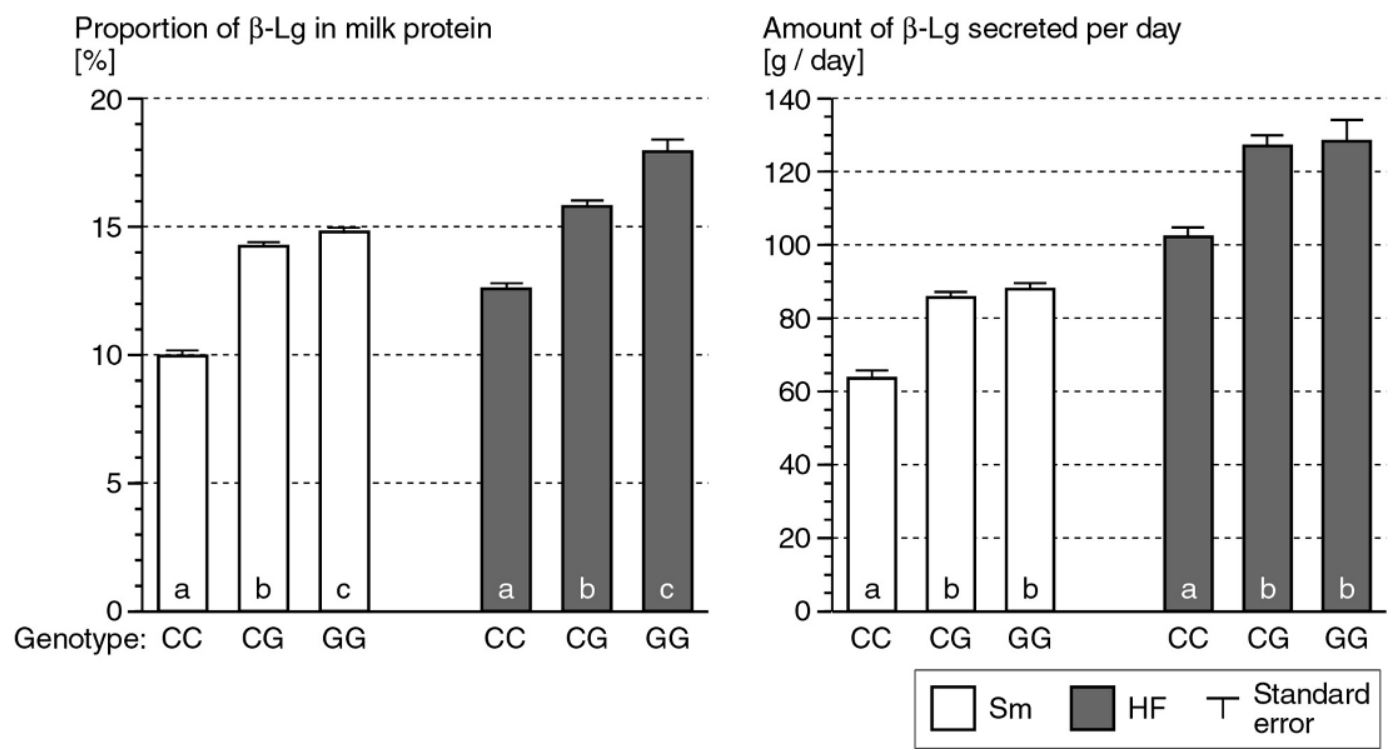

Figure 1. Associations between R10 genotypes and proportion (\%) of the $\beta$-Lg fraction in milk protein as well as daily secreted amount (g/day) of $\beta$-Lg in Sm (white bars) and HF (grey bars). Significant differences $(P<0.01$; t-Test) between genotypes are indicated by different lower-case letters.

$$
\begin{aligned}
\mathrm{LS}_{1}= & \text { fixed effect of lactation stage } \\
\mathrm{S}_{\mathrm{m}}= & \text { fixed effect of season (trimester) } \\
\mathrm{b}_{1}, \mathrm{~b}_{2}= & \text { regression coefficients on cell number }, \\
& \text { linear and squared } \\
\mathrm{C}_{\mathrm{ijklmn}}, \mathrm{C}^{2}{ }_{\mathrm{ijklmn}}= & \text { cell number and cell number squared } \\
\overline{\mathrm{C}}, \overline{\mathrm{C}}^{2}= & \text { mean of cell number and mean of cell } \\
& \text { number squared } \\
\mathrm{e}_{\mathrm{ijklmn}}= & \text { residual effect }
\end{aligned}
$$

\section{RESULTS AND DISCUSSION}

The R10 locus (Wagner et al., 1994) lies in a site for which AP-2 binding activity has been shown (Lum et al., 1997) and for which we could verify allele specific quantitative differences in nuclear protein binding (Kock, 1998). In keeping with the fact that a Guanine in position -435 results in complete homology with the AP-2 consensus sequence (CCCAGGGC), whereas the occurrence of Cytosine causes a decrease in homology, both studies yielded a marked superiority of the G-variant in protein binding. Accordingly, an increased $\beta$ - Lg gene activity in animals carrying R10-G alleles can be assumed. This is mirrored by our results concerning the associations of the R10-G variant with the amount of $\beta$ $\mathrm{Lg}$ secreted per day as well as the proportion of $\beta-\mathrm{Lg}$ in milk protein as shown in Figure 1. Concerning both parameters, there was a significant superiority of Ghomozygotes compared with C-homozygotes in either breed. For GG-cows, higher $\beta$-Lg proportions in milk protein were observed than for heterozygous animals, while the latter and G-homozygotes did not differ significantly as to the daily secreted amount of $\beta$-Lg. Our analyses (Tables 2 and 3 ) also considered $\alpha$-Lactalbumin $\left(\alpha\right.$-La), $\alpha_{\mathrm{S} 1}$-Casein $\left(\alpha_{\mathrm{S} 1}-\mathrm{Cn}\right), \beta$-Casein $(\beta$-Cn) and $\kappa$-Casein $(\kappa$-Cn). In case of the whey protein $\alpha$-La the observed superiority of $\beta$-Lg GG-cows held true for both parameters in the Sm breed whereas in HF there was no significant difference in the amount of $\alpha$-La secreted per day between cows of different R10 genotypes. In the milk of heterozygotes or G-homozygotes of both breeds the percentage of total milk protein was increased as compared to the C-homozygotes (Table 3). However, except for heterozygous Sm which showed lower values for $\alpha_{\mathrm{S1}^{-}}$ Cn than G-homozygotes, daily amounts of $\alpha_{\mathrm{S}^{-}}$and $\beta$ $\mathrm{Cn}$ as well as their proportions in milk protein were lowest in the milk of R10 G-homozygotic animals (Tables 2 and 3$)$.

Similar associations as reported by Ehrmann et al. (1997a) for different variants in the $5^{\prime}$-region of the $\beta$ Lg gene might be due to the very close linkage of these loci with the R10 locus, implying the presence of distinct "intragenic haplotypes" which are stably distributed in the breeds. This interpretation could as well be applied to our results with regard to the $\beta$-Lg protein polymorphism, which also showed associations with the considered milk parameters (Data not shown).

We furthermore observed a connection between cows of different R10 genotypes and milk yield, with C-homozygotes showing the highest values in either breed. Interestingly this is more pronounced in the HF herd with 
Table 2. Associations between R10 genotypes of the AP-2 binding locus in the $5^{\prime}$-flanking region of the $\beta$-Lg gene and amounts of protein fractions and total milk protein secreted per day.

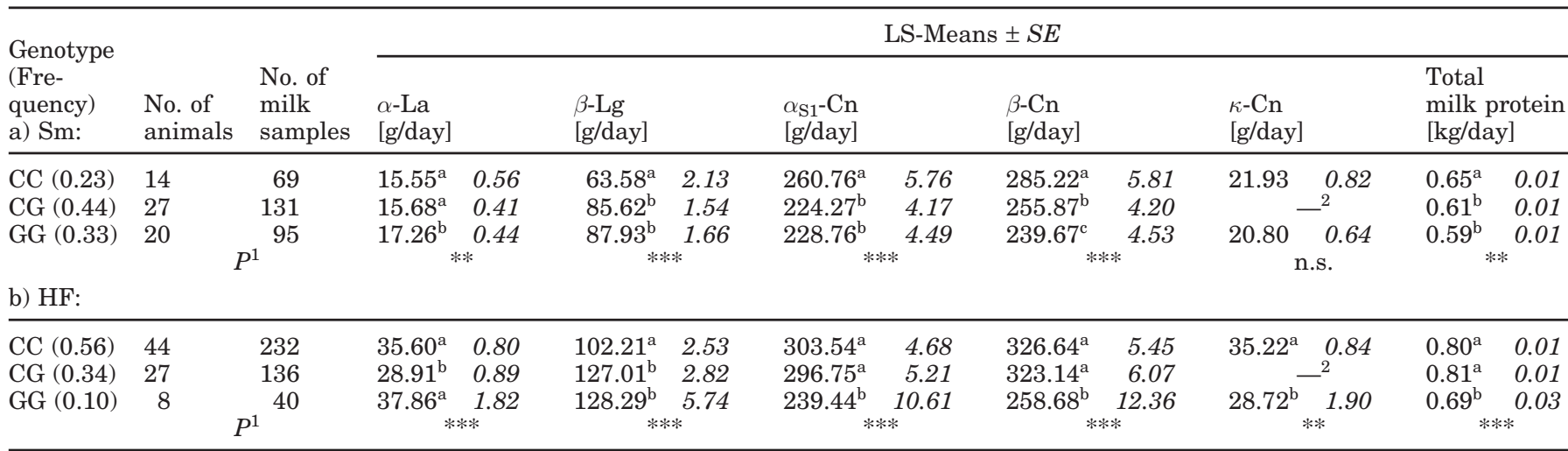

$1 * * * P<0.001, * * P<0.01$ (F-Test); significant differences $(P<0.01 ; \mathrm{t}$-Test) between genotypes are indicated by different letters; n.s.: not significant.

${ }^{2}$ Not considered, due to low precision of trait evaluation.

$25.23 \pm 0.36 \mathrm{~kg}$ milk per day (CC) as compared to 21.41 $\pm 0.82 \mathrm{~kg}(\mathrm{GG})$ than in the Sm herd with $19.0 \pm 0.40 \mathrm{~kg}$ (CC) as compared to $17.27 \pm 0.31 \mathrm{~kg}$ (GG). In both breeds cows with the genotype GG also had lower amounts of total milk protein $(\mathrm{kg} / \mathrm{d})$, mainly caused by a decrease in the casein fraction. The frequencies of the alleles $\mathrm{C}$ and $\mathrm{G}$ were nearly equal among the Sm cows whereas the positively associated allele $\mathrm{C}$ had a frequency of almost 0.73 in the HF herd. This seems to be due to higher milk performance in HF than in Sm but in order to draw a definite conclusion, genotypes of sires with high and low breeding values would have to be investigated in both breeds. In view of the negative effect of R10 GG on milk yield we also suggest that a high resolution QTL analysis of the neighboring chromosomal regions of the $\beta$-Lg gene would reveal putative candidate genes for this trait.
In the Sm herd 14 cows were offspring of the same sire. In order to evaluate possible pedigree influences on our observations we excluded these offspring in a second analysis of the Sm data. The results (not shown) were almost identical with the findings in the complete material. We therefore conclude that the R10 genotype effects are much stronger than sire influences.

Cumulative contribution of the $\beta$ - $\mathrm{Lg} \mathrm{R} 10$ genotypes to the variance explained by the model is given in Figure 2 and showed an especially high influence on $\beta$-Lg parameters in both breeds. We also observed that the environmental factors without herd influence had little impact on the variance of individual milk proteins. On the other hand, environment had a large impact on the daily secretion of milk proteins.

Taken together, our evidence suggests direct effects of the R10 variants of the AP-2 binding site on differen-

Table 3. Associations between R10 genotypes of the AP-2 binding site in the 5 'flanking region of the $\beta$-Lg gene and contents of protein fractions (\% of total milk protein) and total milk protein (\% of whole milk).

\begin{tabular}{|c|c|c|c|c|c|c|c|c|c|c|c|c|c|c|}
\hline \multirow{2}{*}{$\begin{array}{l}\text { Genotype } \\
\text { (Fre- } \\
\text { quency) } \\
\text { a) Sm: }\end{array}$} & \multirow[b]{2}{*}{$\begin{array}{l}\text { No. of } \\
\text { animals }\end{array}$} & \multirow[b]{2}{*}{$\begin{array}{l}\text { No. of } \\
\text { milk } \\
\text { samples }\end{array}$} & \multicolumn{12}{|c|}{ LS-Means $\pm S E$} \\
\hline & & & \multicolumn{2}{|l|}{$\begin{array}{l}\alpha \text {-La } \\
{[\%]}\end{array}$} & \multicolumn{2}{|l|}{$\begin{array}{l}\beta-\mathrm{Lg} \\
{[\%]}\end{array}$} & \multicolumn{2}{|l|}{$\begin{array}{l}\alpha_{\mathrm{S} 1}-\mathrm{Cn} \\
{[\%]}\end{array}$} & \multicolumn{2}{|l|}{$\begin{array}{l}\beta-\mathrm{Cn} \\
{[\%]}\end{array}$} & \multicolumn{2}{|l|}{$\begin{array}{l}\kappa-\mathrm{Cn} \\
{[\%]}\end{array}$} & \multicolumn{2}{|c|}{$\begin{array}{l}\text { Total } \\
\text { milk protein } \\
{[\%]}\end{array}$} \\
\hline $\mathrm{CC}(0.23)$ & 14 & 69 & $2.42^{\mathrm{a}}$ & 0.06 & $9.96^{\mathrm{a}}$ & 0.19 & $39.91^{\mathrm{a}}$ & 0.34 & $44.29^{\mathrm{a}}$ & 0.27 & 3.37 & 0.09 & $3.47^{\mathrm{a}}$ & 0.03 \\
\hline CG (0.44) & 27 & 131 & $2.59^{\mathrm{b}}$ & 0.04 & $14.23^{\mathrm{b}}$ & 0.14 & $37.03^{\mathrm{b}}$ & 0.24 & $42.19^{b}$ & 0.20 & & & $3.65^{b}$ & 0.02 \\
\hline \multirow{2}{*}{ GG $(0.33)$} & 20 & 95 & $2.88^{\mathrm{c}}$ & 0.04 & $14.79^{c}$ & 0.15 & $38.27^{\mathrm{c}}$ & 0.26 & $40.47^{\mathrm{c}}$ & 0.21 & 3.57 & 0.07 & $3.52^{\mathrm{a}}$ & 0.02 \\
\hline & \multicolumn{2}{|c|}{$P^{1}$} & \multicolumn{2}{|c|}{$* * *$} & \multicolumn{2}{|c|}{$* * *$} & \multicolumn{2}{|c|}{$* * *$} & \multicolumn{2}{|c|}{$* * *$} & \multirow{2}{*}{\multicolumn{2}{|c|}{ n.s. }} & \multirow{2}{*}{\multicolumn{2}{|c|}{$* * *$}} \\
\hline \multicolumn{11}{|l|}{ b) HF: } & & & & \\
\hline $\mathrm{CC}(0.56)$ & 44 & 232 & $4.34^{\mathrm{a}}$ & 0.06 & $12.57^{\mathrm{a}}$ & 0.20 & $37.92^{\mathrm{a}}$ & 0.24 & $40.74^{\mathrm{a}}$ & 0.23 & 4.39 & 0.07 & $3.23^{\mathrm{a}}$ & \\
\hline tCG $(0.34)$ & 27 & 136 & $3.48^{\mathrm{b}}$ & 0.07 & $15.78^{\mathrm{b}}$ & 0.23 & $36.79^{b}$ & 0.27 & $39.98^{\mathrm{a}}$ & 0.26 & & ${ }^{2}$ & 3.26 & 0.01 \\
\hline GG $(0.10)$ & 8 & 40 & $5.18^{\mathrm{c}}$ & 0.13 & $17.92^{\mathrm{c}}$ & 0.46 & $35.00^{\mathrm{c}}$ & 0.54 & $37.61^{\mathrm{b}}$ & 0.53 & 4.26 & 0.17 & $3.33^{\mathrm{b}}$ & 0.03 \\
\hline & \multicolumn{2}{|c|}{$P^{1}$} & \multicolumn{2}{|c|}{$* * *$} & \multicolumn{2}{|c|}{$* * *$} & \multicolumn{2}{|c|}{$* * *$} & \multicolumn{2}{|c|}{$* * *$} & & .s. & \multicolumn{2}{|c|}{$* * *$} \\
\hline
\end{tabular}

$1 * * * P<0.001$ (F-Test); significant differences $(P<0.01$; t-Test) between genotypes are indicated by different letters; n.s.: not significant.

${ }^{2}$ Not considered, due to low precision of trait evaluation. 

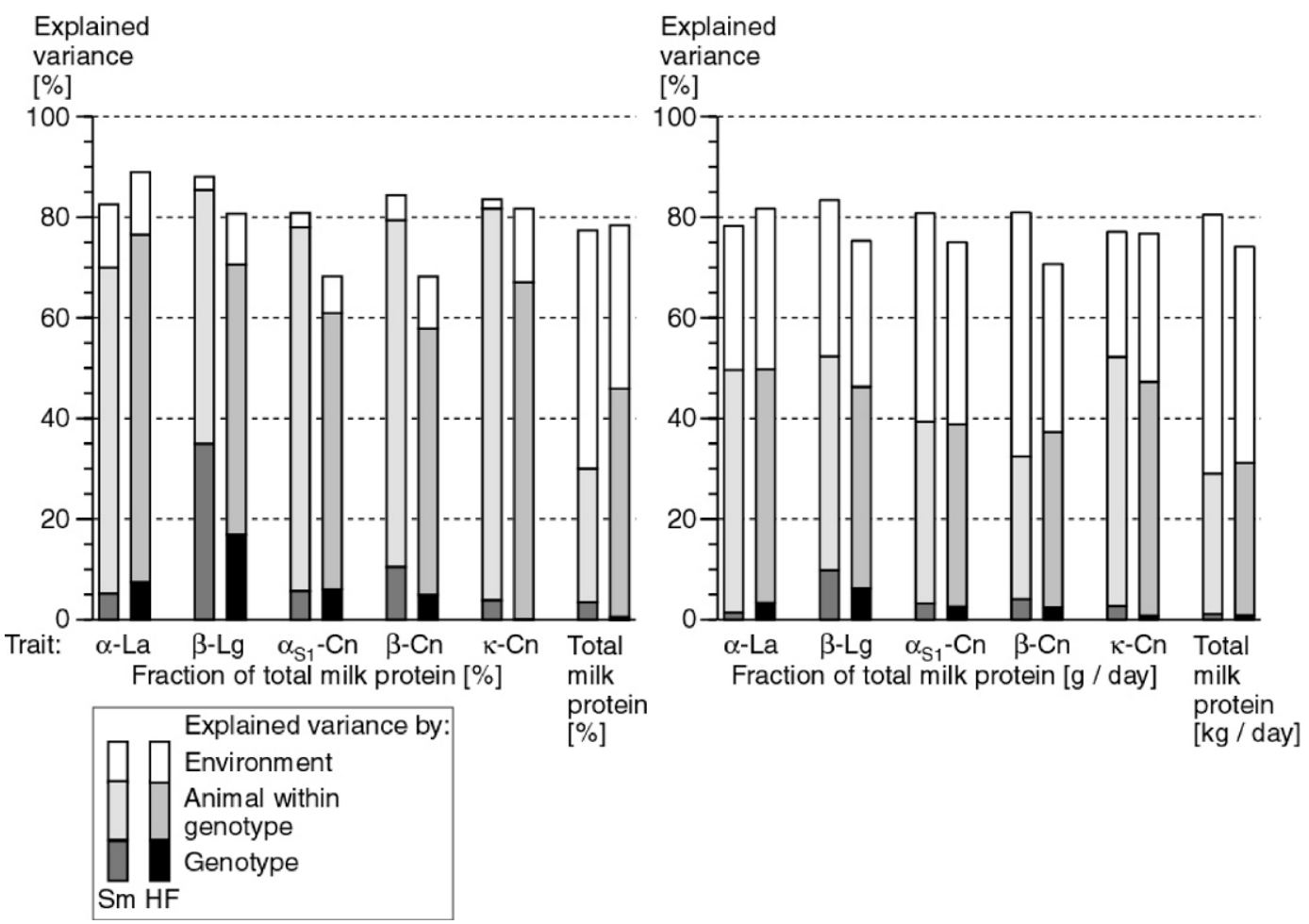

Figure 2. Contribution of the factors genotype, animal, and environment to the variance as explained by the statistical model.

tial expression of the $\beta$-Lg gene. Experiments that have been carried out by Folch et al. (1999) in the murine HC11 cell line showed allelic differences in gene expression between promoter segments including R10 variants. Reciprocal point mutation of R10 alone, however, had very little effect on gene expression results in their study. The authors therefore suggest that this might be due to cooperative effects of the AP-2 element and other polymorphic sites. But in view of the fact that these observations have been made in a murine system in which the bovine $\beta$-Lg promoter has also been shown to be unresponsive to hormonal control (Geldermann et al., 1996), additional evidence needs to be obtained from future studies in the bovine system.

We conclude that the positive association of the R10 $\mathrm{G}$ variant with $\beta$ - $\mathrm{Lg}$ expression is caused by differences in the protein binding capacity of the corresponding AP-2 binding site (Lum et al., 1997; Kock, 1998) while the observed associations with total protein characteristics and with traits of other milk proteins can be interpreted as the results of indirect effects of gene regulation or linkage. Thus our study clearly links a DNA polymorphism of molecular function very closely with in vivo expression parameters of the same locus.

\section{ACKNOWLEDGMENTS}

This study was partly funded by the Deutsche Forschungsgemeinschaft. We also thank Dr. Ayșe De- niz Cardak for her help with electrophoretical and densitometrical analyses of milk samples and Heinz Bartenschlager for statistical analyses.

\section{REFERENCES}

Aschaffenburg, R., and J. Drewry. 1955. Occurence of different betaLactoglobulins in cow's milk. Nature 176:218-219.

Aschaffenburg, R., and J. Drewry. 1957. Genetics of the beta-Lactoglobulins of cow's milk. Nature 180:376-378.

Bell, K., H. A. McKenzie, and D. C. Shaw. 1981. Bovine beta-lactoglobulin E, F and G Bali (Banteng) cattle, Bos (Bibos) javanicus. Aust. J. Biol. Sci. 34:133-147.

Braunitzer, G., R. Chen, B. Schrank, and A. Stangl. 1973. [The sequence of beta-lactoglobulin (author's transl)]. Hoppe Seylers. Z. Physiol Chem. 354:867-878.

Ehrmann, S., H. Bartenschlager, and H. Geldermann. 1997a. Polymorphism in the $5^{\prime}$-flanking region of the bovine lactoglobulin encoding gene and its association with beta-lactoglobulin in the milk. J. Anim. Breed. Genet. 114:49-53.

Ehrmann, S., H. Bartenschlager, and H. Geldermann. 1997b. Quantification of gene effects on single milk proteins in selected groups of dairy cows. J.Anim.Breed.Genet. 114:121-132.

Eigel, W. N., J. E. Butler, C. A. Ernstrom, H. M. Farrell, Jr., V. R. Harwalkar, R. Jennes, and R. M. Whitney. 1984. Nomenclature of Proteins of Cow's Milk: Fifth Revision. J. Dairy Sci. 67:1599-1631.

Folch, J. M., P. Dovc, and J. F. Medrano. 1999. Differential expression of bovine beta-lactoglobulin A and B promoter variants in transiently transfected HC11 cells. J. Dairy Res. 66:537-544.

Geldermann, H., J. Gogol, M. Kock, and G. Tacea. 1996. DNA variants within the $5^{\prime}$-flanking region of bovine milk protein encoding genes. J. Anim. Breed. Genet. 113:261-267.

Godovac-Zimmermann, J., I. Krause, M. Baranyi, S. Fischer-Fruhholz, J. Juszczak, G. Erhardt, J. Buchberger, and H. Klostermeyer. 1996. Isolation and rapid sequence characterization of 
two novel bovine beta-lactoglobulins I and J. J. Protein Chem. 15:743-750.

Godovac-Zimmermann, J., I. Krause, J. Buchberger, G. Weiss, and H. Klostermeyer. 1990. Genetic variants of bovine beta-lactoglobulin. A novel wild-type beta-lactoglobulin $\mathrm{W}$ and its primary sequence. Biol. Chem. Hoppe Seyler 371:255-260.

Kaminski, S., and T. Zabolewicz. 2000. Associations between bovine beta-lactoglobulin polymorphism within coding and regulatory sequences and milk performance traits. J. Appl. Genet. 41:91-99.

Kock, M. 1998. Einfluß von Varianten im 5' flankierenden Bereich Milchprotein codierender Gene auf die Bindungsaktivität von Transkriptionsfaktoren. Diss., University of Hohenheim, Stuttgart, Germany.

Lum, L. S., P. Dovc, and J. F. Medrano. 1997. Polymorphisms of bovine beta-lactoglobulin promoter and differences in the binding affinity of activator protein-2 transcription factor. J. Dairy Sci. 80:1389-1397.

Lunden, A., M. Nilsson, and L. Janson. 1997. Marked effect of betalactoglobulin polymorphism on the ratio of casein to total protein in milk. J. Dairy Sci. 80:2996-3005.

McLean, D. M., E. R. Graham, R. W. Ponzoni, and H. A. McKenzie. 1984. Effects of milk protein genetic variants on milk yield and composition. J. Dairy Res. 51:531-546.

Perez, M. D., and M. Calvo. 1995. Interaction of beta-lactoglobulin with retinol and fatty acids and its role as a possible biological function for this protein: a review. J. Dairy Sci. 78:978-988.

Wagner, V., T. A. Schild, and H. Geldermann. 1994. DNA variants within the 5 'flanking region of milk-protein-encoding genes II. The beta-Lactoglobulin encoding gene. Theor. Appl. Genet. 89:121-126. 